\title{
Cocos (Keeling) Islands
}

National Cancer Institute

\section{Source}

National Cancer Institute. Cocos (Keeling) Islands. NCI Thesaurus. Code C16445.

A group of islands in the Indian Ocean, south of Indonesia and west of Christmas Island. 